\title{
Surgical Therapy for Craniocerebral Firearm Injury
}

\section{Kraniyoserebral Ateşli Silah Yaralanması İçin Cerrahi Tedavi}

\author{
Liang-Feng WEI, Shou-Sen WANG, Jun-Jie JING, Zhao-Cong ZHENG, Jin-Xi GAO, Zheng LIU, Ru-Mi WANG \\ Fuzhou General Hospital, Fujian Medical University, Department of Neurosurgery, Fuzhou, China
}

Corresponding Author: Liang-Feng WEI / E-mail: 1frmcn@126.com

\begin{abstract}
AIM: The current study aims to explore the clinical characteristics of craniocerebral firearm injury and to improve the diagnosis and treatment of this condition.

MATERIAL and METHODS: Data from 56 patients with craniocerebral firearm injury were analyzed retrospectively for projectile types, traumatic conditions, and treatment approaches.

RESULTS: 43 patients exhibited intracranial foreign body residence. Of them, 40 were subjected to complete foreign body removal and 2 to partial removal, leaving 1 without receiving removal treatment. 54 patients (96.4\%) survived and 2 (3.6\%) died. Of the survivors, 36 (64.3\%) recovered well, 15 (26.8\%) were moderately disabled, 2 (3.6\%) were severely disabled, and 1 (1.8\%) lapsed into vegetative state. Patients receiving debridement within $8 \mathrm{~h}$ after injury had a significantly higher recovery rate than those receiving such treatment after $8 \mathrm{~h}(82.1 \% \mathrm{vs}$. 26.7\%; $P<0.001)$.

CONCLUSION: Craniocerebral firearm injury is characterized by rapid traumatic condition development as well as serious trauma and contamination. Accurately judging the traumatic condition and the ballistic tract, performing complete debridement as early as possible, reasonably deciding on the operative mode and approach for intracranial residing foreign body removal, and increasing vigilance regarding concomitant injuries are the keys to the improvement of the overall treatment of craniocerebral firearm injury.
\end{abstract}

KEYWORDS: Craniocerebral injury, Firearm injury, Surgery

öz

AMAÇ: Mevcut çalışma kraniyoserebral ateşli silah yaralanmasının klinik özelliklerini incelemeyi ve böyle bir durumun tanı ve tedavisini geliştirmeyi amaçlamaktadır.

YÖNTEM ve GEREÇLER: Kraniyoserebral ateşli silah yaralanması olan 56 hastanın verileri projektil tipleri, travmatik durumlar ve tedavi yaklaşımları açısından retrospektif olarak incelendi.

BULGULAR: 43 hastada intrakraniyal yabancı cisim vardı. Bunlar içinde 40'ında yabancı cisim tamamen çıkarılırken 2'sinde kısmen çıkarıldı ve 1 hastada çıkarma için işlem yapılmadı. 54 hasta $(\% 96,4)$ yaşadı ve 2 hasta $(\% 3,6)$ öldü. Yaşayanlar içinde 36'sı $(\% 64,3)$ iyi iyileşti, 15'i $(\% 26,8)$ orta derecede engelli kaldı, 2'si $(\% 3,6)$ şiddetli engelli kaldı ve 1'i $(\% 1,8)$ vejetatif duruma girdi. Yaralanmadan sonraki 8 saat içinde debridman yapılan hastalarda iyileşme oranı bu tedavinin 8 saatten sonra yapıldığı hastalara göre çok daha iyiydi (\%82,1 vs. \%26,7; P<0.001).

SONUÇ: Kraniyoserebral ateşli silah yaralanması hızlı travmatik durum gelişmesi ve ayrıca ciddi travma ve kontaminasyonla ilişkilidir. Travmatik durumu ve balistik yolu doğru olarak belirlemek, mümkün olduğunca erken dönemde tam debridman yapmak, operatif mod ve intrakraniyal kalmış yabancı cismin çıkarılmasına yaklaşıma makul bir şekilde karar vermek ve eş zamanlı yaralanmalar açısından dikkatli olmak kraniyoserebral ateşli silah yaralanmalarında genel tedavi düzeyini arttırmanın temelleridir.

ANAHTAR SÖZCÜKLER: Kraniyoserebral yaralanma, Ateşli silah yaralanması, Cerrahi

\section{INTRODUCTION}

Craniocerebral firearm injury has a high incidence in modern wars, or in areas where armed conflicts break out or riots frequently happen $(6,9,16,17)$. It is also sometimes caused by gun suicide $(3,12)$. Craniocerebral firearm injury is characterized by high mortality and disability, accounting for nearly $50 \%$ of total deaths caused by firearm injury since World War II (22). Sudden occurrence, uncertainties of trauma types, specific injured locations and severity, as well as differences in craniocerebral structure, age, and physical status among patients all contribute to the extreme complexity and severity of modern craniocerebral firearm injury. In addition, considering that civilian firearm number and the power of new weapons and ammunition are increasing nowadays, more wide-range and severe injuries are certain to develop. Therefore, craniocerebral firearm injury-caused disability and deaths have even become a serious social problem (7).

Previously, most studies on craniocerebral firearm injury focused on the exploration of its treatment based on analysis from one or a few angles and thus lack integrity and comprehensiveness. To accurately understand the characteristics of craniocerebral firearm injury, improve its 
diagnostic level and perform rational and effective surgical treatment immediately have become great concerns of surgeons.

In this study, clinical data from and treatments for 56 patients with craniocerebral firearm injury at Fuzhou General Hospital from August 1966 to May 2009 were analyzed retrospectively. The aims were to explore and summarize the clinical characteristics, operation timing, and operation mode of craniocerebral firearm injury and to provide a basis for reducing resultant disability and mortality rates.

\section{DATA and METHODS}

\section{General Data}

50 males (89.3\%) and 6 females (10.7\%) were involved in this study. Their ages ranged from 2 years to 52 years with an average of 24.1 ( 5 patients between 2 years and 10 years, 13 between 11 and 20, 22 between 21 and 30, 11 between 31 and 40 , and 5 between 41 and 52). They were hospitalized $3 \mathrm{~h}$ to $16 \mathrm{~d}$ after injury with an average of $21.3 \mathrm{~h}$.

\section{Causes}

Seven cases (12.5\%) were caused by conventional weapons (pistols, rifles, and machine guns), 19 (33.9\%) by knocking weapons (shells, land mines, grenades, and detonators), and 30 (53.6\%) by civilian guns (shotguns and air guns).

\section{Injured Sites and Injury Types}

23 patients (41.1\%) had injury at the frontal part, 16 (28.6\%) at the temporal part, $12(21.4 \%)$ at the copular part, $4(7.1 \%)$ at the occiput, and $1(1.8 \%)$ at the posterior cranial fossa. 10 patients $(17.9 \%)$ also presented with maxillofacial injury, 13 (23.2\%) with thoracic injury, 3 (5.4\%) with abdominal injury, and $2(3.6 \%)$ with limb injury. 11 patients (19.6\%) had a penetrating wound, $3(5.4 \%)$ had a tangential wound, 41 (73.2\%) had a blind tract wound, and $1(1.8 \%)$ had a ricochet wound.

\section{Admission Conditions}

All patients were scored using Glasgow coma scoring: 5 patients (8.9\%) got scores between 3 and 5 points, 45 (80.4\%) between 6 and 8, 4 (7.1\%) between 9 and 12, and 2 (3.6\%) between 13 and 15.51 patients (91.1\%) exhibited varying degrees of consciousness disturbance and 5 (8.9\%) did not show such a manifestation. 45 patients $(80.4 \%)$ had mydriasis, of whom 25 (44.6\%) had unilateral mydriasis and 20 (35.7\%) had bilateral mydriasis. 16 patients $(28.6 \%)$ presented with hemiplegia, 28 (50.0\%) with hypermyotonia, 12 (21.4\%) with decerebrate rigidity, $26(46.4 \%)$ with positive pyramid sign, and 5 (8.9\%) with seizure disorder. 9 cases (16.1\%) were complicated with epidural hematoma, 12 (21.4\%) with subdural hematoma, 3 (5.4\%) with traumatic subarachnoid hemorrhage, 15 (26.8\%) with extensive cerebral contusion and laceration, 19 (33.9\%) with intracerebral hematoma, 5 (8.9\%) with brain stem injury, 1 (1.8\%) with hypothalamus injury, 1 (1.8\%) with cerebellar laceration, 1 (1.8\%) with large cerebral infarction, and 2 (3.6\%) with optic nerve injury. 17 patients (30.4\%) suffered from shock, 12 (21.4\%) had pulmonary infection, 9 (16.1\%) had upper gastrointestinal hemorrhage, 2 (3.6\%) had intracranial abscess, $4(7.1 \%)$ had fluid and electrolyte imbalance, 3 (5.4\%) had kidney insufficiency, and 3 (5.4\%) did not have the aforementioned complications.

\section{Auxiliary Examination}

All patients were subjected to radiological examination (X-rays, cerebral angiography, computed tomography (CT), or magnetic resonance imaging (MRI)) for the understanding of wound tracts, the number and location of intracranial residing metallic foreign bodies or bone chips, and complications such as intracranial hematoma and brain edema (Figures $1 A, B$; $2 A, B)$.

\section{Surgical Methods}

Debridement, hematoma evacuation, and decompressive craniectomy were performed as early as possible. Hair, sediment, bone chips, metallic foreign bodies, and necrotic liquefied tissues in the ballistic tract were completely removed. The wound tract was washed repeatedly with hydrogen peroxide, antibiotics, and physiological saline. For patients with intracranial residing foreign bodies, surgicallytouchable superficial foreign bodies were removed during debridement, deep and tiny foreign bodies were taken out using the stereotaxis or neuronavigation technique, and metallic foreign bodies that were difficult to clamp were removed using a magnetic bar or guide pin. For patients complicated with skull base defect, skull base repair and reconstruction were performed. A total of 54 patients (96.4\%) received surgical treatment: $40(71.4 \%)$ received debridement and complete foreign body removal, 2 (3.6\%) received debridement and partial foreign body removal, and $12(21.4 \%)$ received debridement alone. 2 patients (3.6\%) received conservative treatment. Debridement within $8 \mathrm{~h}$ after injury was performed for 39 patients (69.6\%) and that after $8 \mathrm{~h}$ for 15 (8.9\%).

\section{Statistical Analysis}

Data were analyzed by SPSS 13.0 software. $\chi^{2}$ tests were performed for numeration data. $P<0.05$ was considered statistically significant.

\section{RESULTS}

\section{Foreign Body Removal}

In this study, 43 patients presented with intracranial residence of one or multiple foreign bodies. Complete removal was performed for 40 patients (93.0\%) and partial removal for 2 because multiple tiny metallic projectiles resided under the scalp (Figure 1A,B). One patient did not receive removal treatment because the foreign bodies were located in the deep functional areas. Intraoperative stereotaxis was adopted for 15 patients (Figure $2 \mathrm{~A}, \mathrm{~B}$ ) and intraoperative neuronavigation for 2 (Figure 3). 


\section{Curative Effect}

54 of the 56 patients survived and 2 deaths occurred. The deaths were caused by severe extensive cerebral contusion and laceration (1 case) and multiple organ failure (1 case). The survivors were followed up and the curative effects were graded according to Glasgow outcome scoring criteria: 36 patients (64.3\%) recovered well, $15(26.8 \%)$ were moderately disabled, and $2(3.6 \%)$ were severely disabled. Among the 36 patients that recovered well, $32(82.1 \% ; 32 / 39)$ received debridement within $8 \mathrm{~h}$ after injury and 4 (26.7\%; $4 / 15)$ received debridement after $8 \mathrm{~h}$, showing a significant difference $(P<0.001)$.

\section{DISCUSSION}

To deepen the understanding of craniocerebral firearm injury and to increase its diagnosis and treatment level, the clinical data from 56 patients with craniocerebral firearm injury as well as their treatment results were analyzed retrospectively in this study. 40 of 43 patients exhibiting intracranial foreign body residence $(93.0 \%)$ underwent direct-visual complete foreign body removal under the guide of the stereotaxis or neuronavigation technique. After treatment, 54 patients survived, accounting for $96.4 \%$ of all the patients. Furthermore, patients receiving debridement within $8 \mathrm{~h}$ after injury got a
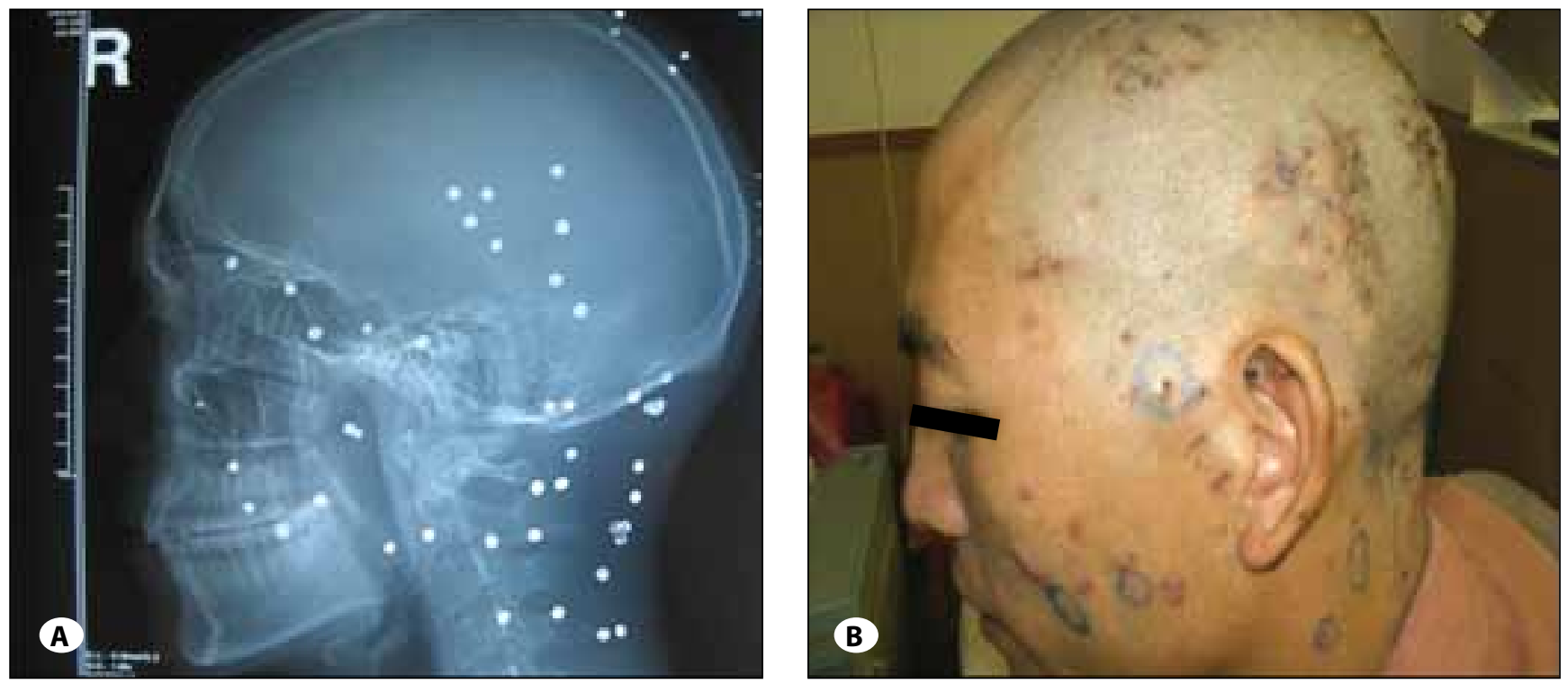

Figure 1: Residence of multiple metallic bullets under the scalp on the left side after shotgun injury. A) A cranial X-ray frontal film; B) The preoperative skin mark at the operative site.
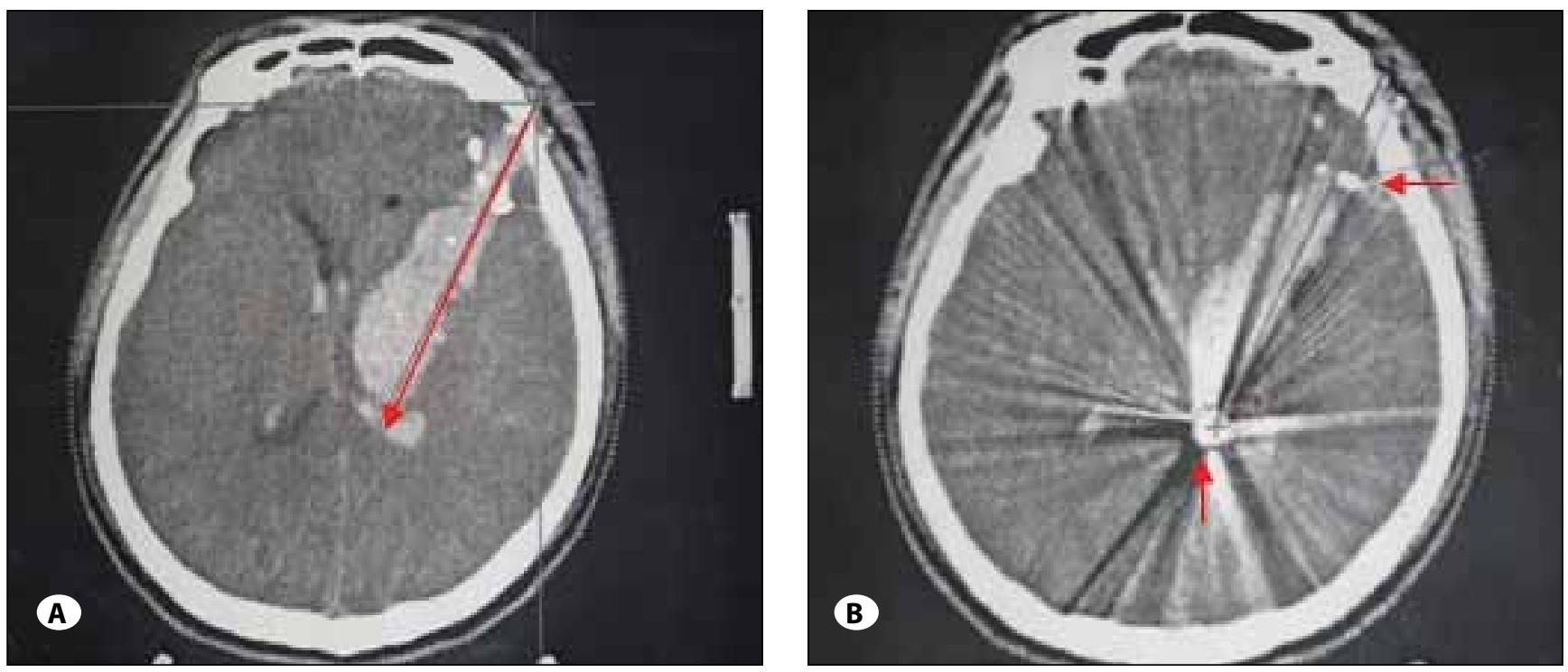

Figure 2: Head CT scan after grenade injury. A) The oblique ballistic tract with a length of about $13 \mathrm{~cm}$ from the left prefrontal temporal lobe to the basal ganglia (indicated by the oblique arrow); B) Bullet fragments (indicated by the downward arrow), bone fragments (indicated by the horizontal arrow), and hematoma in the ballistic tract concurrent with brain swelling. 


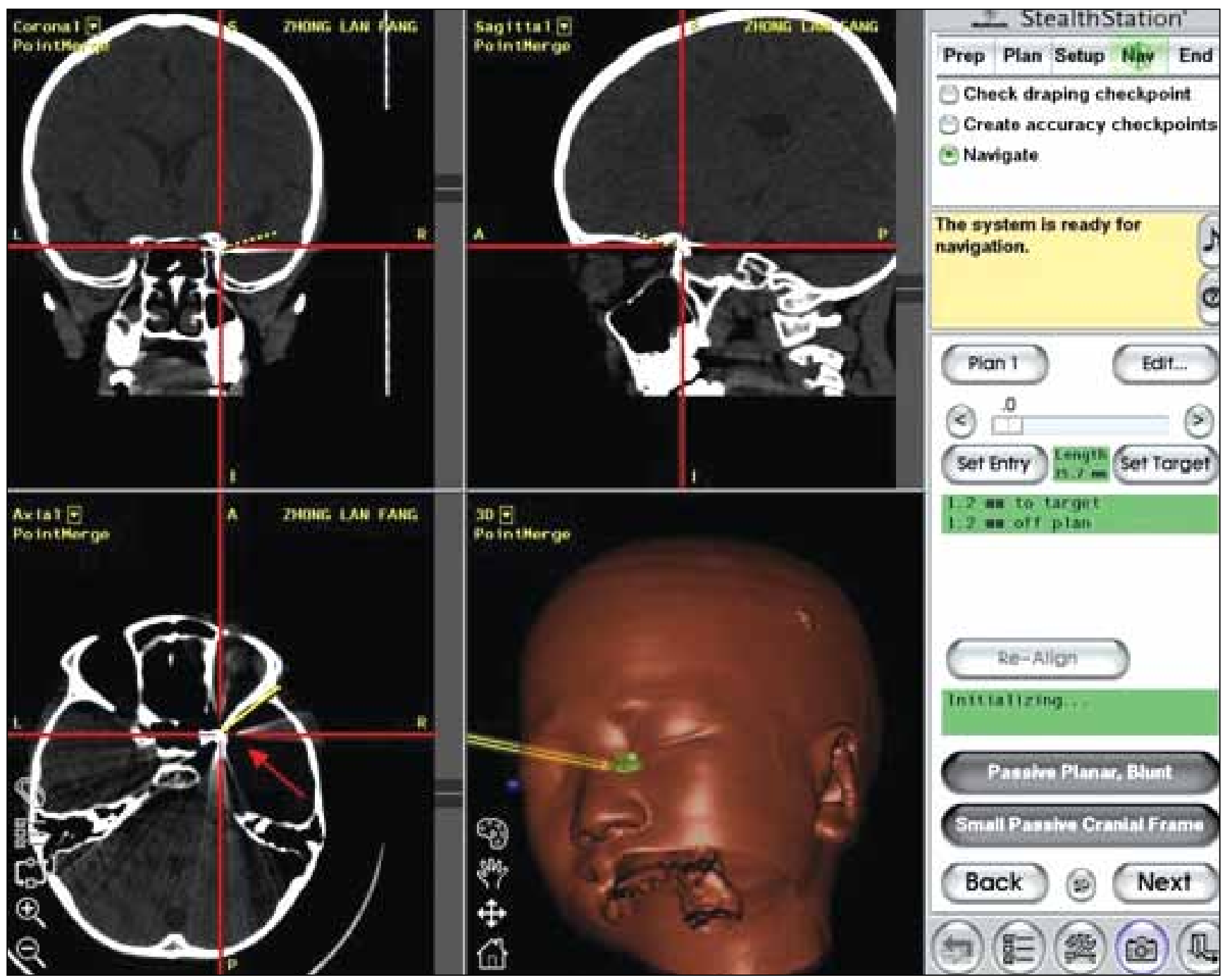

Figure 3: Neuronavigation positioning of the residing metallic foreign bodies in the posterior wall of the right orbital cavity (shown by the oblique arrow).

higher recovery rate than those receiving debridement after $8 \mathrm{~h}$ of injury.

The injury mechanism of firearm injury can be simply summarized as the combined action of air pressure, fragments, thermal effect, chemical stimulation, and detonation (20). After a projectile enters the skull, it generates a powerful lateral pressure that acts on the surrounding tissues and compresses them promptly to form a temporary cavity (the cavity can have a diameter dozens of times as large as that of the primary wound tract). At this very moment, intracranial pressure increases abruptly. However, immediately after that, the air pressure in the cavity vanishes within several milliseconds and elastic recoil occurs. These sudden changes cause extensive and serious damage to cerebral tissues. Fragments may include projectiles, as well as secondary projectiles (such as broken bone fragments). The thermal effect causes skin and cerebral tissue burns. Ammunition with specific properties results in chemical stimulation.
Detonation can lead to irreversible damage to the internal acoustic meatus. The wounding effect of a projectile is not only correlated with its weight, velocity, shape, and structure but closely correlated with the structural characteristics of the injured tissue (21). Craniocerebral injury caused by a highvelocity projectile is markedly more severe than that caused by a low-velocity one (13).

Craniocerebral firearm injury therefore possesses the characteristics of rapid traumatic condition development and serious trauma and contamination compared with non-firearm injury. It causes a post-surgery mortality rate of approximately $20 \%(2,4,515)$. As for craniocerebral firearm injury caused by civilian suicide, the mortality rate may be as high as $88 \%$ (1). In this study, no patients got involved in a suicide event. In addition, except for three patients injured by high-velocity projectiles (rifles or machine guns), all were injured by low-velocity projectiles (civilian guns). These factors partially contributed to the reduced severity of the 

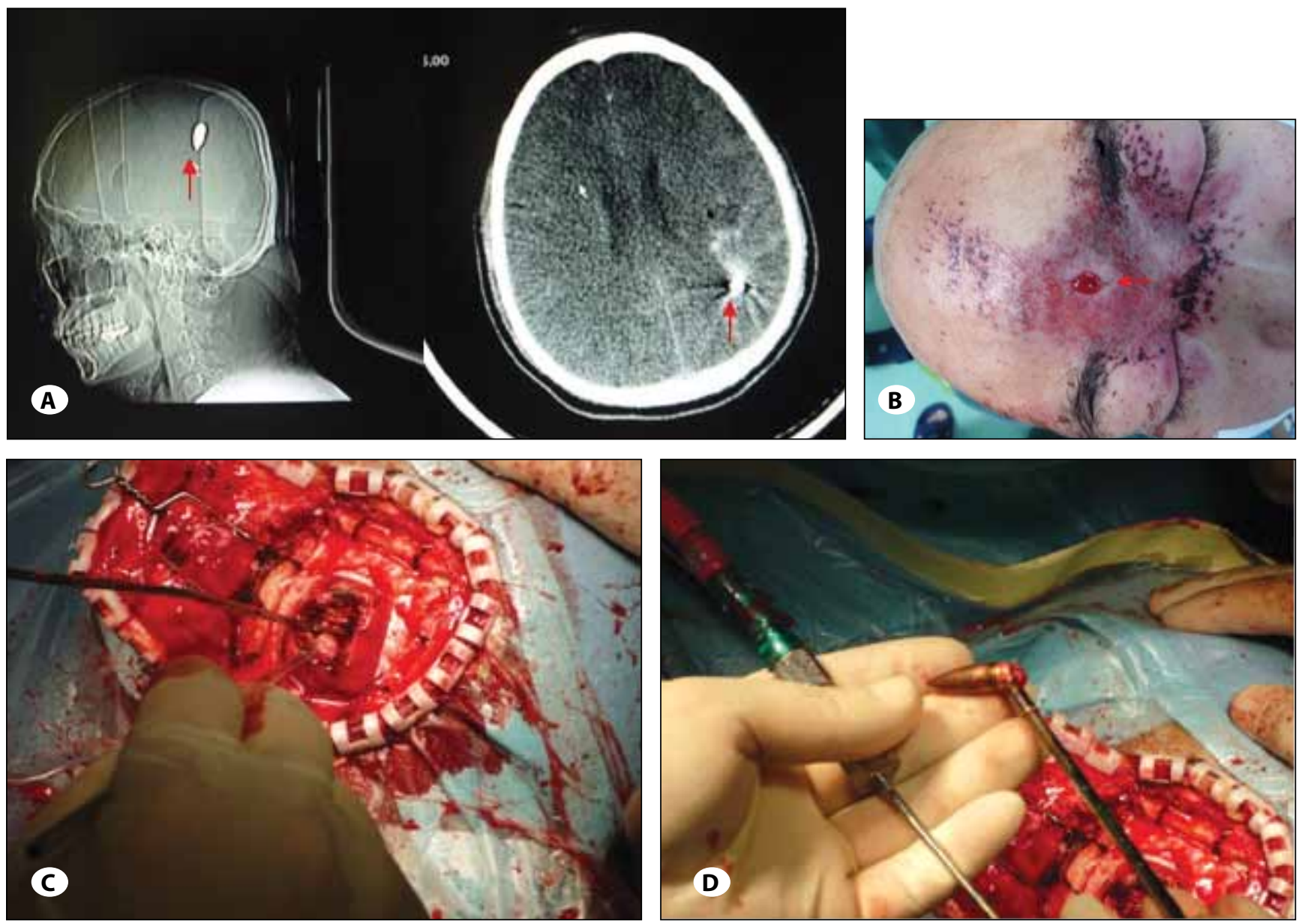

Figure 4: A) Head X-rays and CT show metallic bullets at the left parieto-occipital site as well as local hemorrhage in a small amount and edema (indicated by the arrow) at the left occipital lobe; B) The bullet entrance between the eyebrows (the arrow) and widelyranged skin burns around the entrance; $\mathbf{C}$ ) The inserted magnetic bar for bullet removal; and $\mathbf{D}$ ) The removed bullet.

general traumatic condition and a post-treatment survival rate of $96.4 \%$ in this study. The three patients injured by high-velocity projectiles received debridement, hematoma evacuation, and decompressive craniectomy, but the curative effects were unsatisfactory due to severe extensive cerebral contusion and swelling: one died, one was seriously disabled, and one was moderately disabled.

Craniocerebral firearm injury can be diagnosed using routine anterioposterior and lateral $\mathrm{X}$-rays. If the projectile entrance is located at the occiput, occipital-frontal (Town position) X-rays should be supplemented for the interest of determining injury type, as well as the location and number of intracranial metallic foreign bodies and bone fragments. This examination method has a particular advantage in evaluating the range of shotgun injury. Furthermore, cranial X-ray films are convenient for head surface metallic marker positioning in clinical practice, thereby benefiting accurate intraoperative foreign body removal. CT scan is indispensable after craniocerebral firearm injury. Preoperative thin-layer plain CT scan and bone window scan can expose the location and direction of the wound tract, the properties and number of foreign bodies, the position relations of the foreign bodies with the skull, venous sinus and cerebral functional areas, as well as conditions such as intracranial hemorrhage and cerebral edema. They can also play an assistant role in judging the direction, angle, and distance of the projectile. Projectile's intracranial bounding can cause a refracted wound tract. Multiple cerebral injuries caused by such a tract can also be observed by carefully observing CT films. Although MRI achieves a higher degree of accurate cerebral tissue injury observance, it should be cautiously used or even prohibited in diagnosis after craniocerebral firearm injury because of the possible residence of metallic foreign bodies. Normally, MRI is only used for diagnosing penetrating wound or observing and judging the traumatic condition after bullet fragment removal. In addition, although cerebral angiography is rarely used for the diagnosis of craniocerebral firearm injury nowadays, it still has significant diagnostic value for complicated intracranial aneurysm or arteriovenous fistula.

Knowledge of wound ballistics plays an important role in better understanding craniocerebral ballistic injury condition (11). In this study, patients' traumatic conditions varied 
according to different kinetic energy and shapes of projectiles. Short-distance bullet injury often causes penetrating injury because of high kinetic energy of projectiles. As a result, skull fractures, cerebral contusion and laceration, intracranial hematoma, and consciousness disorder occur, causing serious traumatic condition. In contrast, long-distance bullet and explosive weapon injury often results in blind tract wound. Although civilian guns have low kinetic energy and patients with so-caused blind tract wound only have slight consciousness disorder in most cases, extensive multi-bolus residence and serious contamination tend to occur. As for post-injury residing foreign bodies, non-metallic materials are the primary form in penetrating and tangential wound, whose components are represented by dandruff, hair, and cranioaural fragments carried in by bullets, whereas metallic materials are the representative form in blind tract wound. However, some patients may exhibit the co-residence of metallic and non-metallic foreign bodies.

Timely discovering intracranial hematoma and performing debridement and hematoma evacuation can noticeably reduce the mortality and disability rates of patients with craniocerebral injury (19). For patients with serious brain damage accompanied by the residence of cranioaural fragments, bullet fragments, or pellets, complete debridement is necessary; the procedure should be performed under direct vision as far as possible $(8-10,13,16,18)$. Also, surgery can be performed under the guide of operating microscope or nerve endoscope (14). Normally, craniocerebral firearm injury has an infection incidence of 20-45.7\%. However, under specific conditions such as high temperature and high humidity, earlier and more severe infection may occur, because of faster proliferation of bacteria after firearm injury. In this study, because most patients were farmers from remote rural areas and front-line soldiers, they were hospitalized after long time of transportation or delay. As a result, only 5 of 54 patients received debridement within $6 \mathrm{~h}$ after injury, 34 between $6 \mathrm{~h}$ and $8 \mathrm{~h}$, and 15 after $8 \mathrm{~h}$. Because of only a small number of patients receiving debridement within $6 \mathrm{~h}, 8 \mathrm{~h}$ was taken as the dividing line in this study. The result showed that patients receiving debridement within $8 \mathrm{~h}$ after injury got a significantly higher recovery rate than those receiving debridement after $8 \mathrm{~h}$ of injury. Therefore, performing complete debridement as early as possible is the key to successful treatment of craniocerebral firearm injury. The aim of early debridement after injury is to reduce the risk of infection and meanwhile to alleviate the severity of secondary cerebral edema. In addition, turning an open and contaminated wound tract into a closed and clean tract, the following steps should also be done during debridement: the removal of intracranial hematoma, broken necrotic cerebral tissues and foreign bodies in the operating field and wound tract, strict hemostasis, repeated washing of the wound tract with gentamycin sulfate saline or hydrogen peroxide, and repair to dural and scalp defects. For cases concurrent with severe cerebral edema, decompressive craniectomy can be performed. After operation, broad-spectrum antibiotics were given routinely.

Intracranial foreign body removal should be performed on the premise of being without worsening cerebral injury. Therefore, the determination of a reasonable operative mode as well as a plausible approach should be based on traumatic condition as well as the characteristics of the wound tract. This study generates the following experiences in this respect: 1) For a short wound tract and superficial foreign bodies, debridement and foreign body removal can be performed through the projectile entrance; 2) For foreign bodies located in functional areas, apart from ballistic debridement, an incision and an operative approach should be designed to remove the foreign bodies avoiding the functional areas; 3 ) For blind tract injury with a long wound tract and foreign bodies very close to the inner table of the skull on the opposite side, debridement should be done from the entrance; in addition, an incision for foreign body removal should be made at the place close to the foreign bodies on the opposite side or avoiding important functional areas; 4) For a tract caused by ricochet wound, bilateral craniotomy along the ballistic tract and bidirectional debridement should be performed; afterwards, foreign bodies were taken out on the proximal side; 5) Because both stereotaxis and neuronavigation can miniaturize and intelligentize the surgical pathway, their application improve the overall quality of surgery; 6) For metallic foreign bodies with small volumes deeply located in vital structure whose removal can pose a disability or even life risk, or non-penetrating foreign bodies with diameters of less than $1 \mathrm{~cm}$ deeply located in the muscles at the temple or occiput, removal may not be necessarily performed; however, for lead bullets and cranial bone fragments, removal should be tried as much as possible; otherwise, they may increase the risks of toxicity and infection; and 7) For metallic foreign bodies that are not easily clamped out, a magnetic bar or pin can be used.

The patient involved in Figure $2 A, B$ was a 20-year-old male soldier who was hospitalized $1 \mathrm{~h}$ after coma and hemiplegia caused by grenade injury. CT scan showed hematoma in the ballistic tract from the left frontotemporal lobe to the basal ganglia and the residence of a bullet fragment near the midline posterior to the basal ganglia. With the help of a Fischer brain stereotactic apparatus and a surgery microscope, a surgery was performed under a systemic anaesthesia. A debridement pathway was first designed in the direction of the ballistic tract. However, due to the obstruction of the middle cerebral artery and its branches in the lateral fissure area, the surgery could not proceed deeply. Thus, a cortical incision in the upper part posterior to the bone window was decided and the bullet fragment was suctioned using a magnetic pin. After the surgery, his consciousness and muscle strength recovered gradually. The patient involved in Figure 4A-D was a 36-yearold male security officer who was hospitalized $8 \mathrm{~h}$ after coma caused by handgun injury of the head. Frontal debridement was performed immediately. A prefrontal bone cavity and an anterior basilar fracture with free bone fragments were 
observed. The fragments were taken out. Hematoma and broken necrotic cerebral tissues were cleaned. The mucous membrane of the frontal sinus was removed. Basicranial defects were plugged by bone wax and then pasted and reinforced by gelatin sponge and EC glue. Craniotomy at the left occiput was performed by making a horseshoe incision for hematoma and blood clot removal. A magnetic bar was inserted and a metallic bullet with a length of about $2 \mathrm{~cm}$ was suctioned out. Because the patient exhibited marked cerebral swelling, decompressive craniectomy was performed.

Diagnosing the concomitant injuries of craniocerebral firearm injury as early as possible is of great significance for patients' prognosis. Based on the analysis of this study, explosive weapon injury is most likely to be associated with associated injuries. Since most patients with such injury stay in coma at the time of doctors' office visiting, doctors tend to concentrate on craniocerebral injury only and thereby neglect associated injuries. Therefore, if a patient exhibits dyspnea, chest injury should not be out of consideration. In addition, although abdominal paracentesis is a convenient and reliable diagnostic method for injury of abdominal parenchymal viscera, a first-time negative result cannot exclude the possibility of such a condition. In this study, negative results were obtained from 4 patients in coma after the first time of abdominal paracentesis. However, the second and third abdominal paracenteses demonstrated positive results. Furthermore, for patients accompanied by paralysis, spinal column, spinal cord, and limb injuries should be on the alert.

Craniocerebral firearm injury is characterized by rapid traumatic condition development as well as serious trauma and contamination. Accurately judging traumatic condition and the ballistic tract, performing complete debridement as early as possible, reasonably deciding an operative mode and an approach for concomitant intracranial foreign body removal on the premise of being without exaggerating cerebral injury, and timely discovering and managing the associated injuries of other important organs are the keys to the improvement of the overall treatment level of craniocerebral firearm injury.

\section{REFERENCES}

1. Aldrich EF, Eisenberg HM, Saydjari C, Foulkes MA, Jane JA, Marshall LF, Young $\mathrm{H}$, Marmarou A: Predictors of mortality in severely head-injured patients with civilian gunshot wounds: A report from the NIH Traumatic Coma Data Bank. Surg Neurol 38:418-423, 1992

2. Becker DP, Miller JD, Ward JD: The outcome from severe head injury with early diagnosis and intensive management. J Neurosurg 47:491-502, 1977

3. Blumenthal R: Suicidal gunshot wounds to the head: A retrospective review of 406 cases. Am J Forensic Med Pathol 28:288-291, 2007

4. Carey ME, Young $\mathrm{H}$, Mathis $\mathrm{J}$, Forsythe J: A bacteriological study of craniocerebral missile wounds from Vietnam. J Neurosurg 34(2 Pt 1):145-154, 1971
5. Caveness WF, Meirowsky AM, Rish BL, Mohr JP, Kistler JP, Dillon JD, Weiss GH: The nature of posttraumatic epilepsy. J Neurosurg 50:545-553, 1979

6. Cina SJ, Ward ME, Hopkins MA, Nichols CA: Multifactorial analysis of firearm wounds to the head with attention to anatomic location. Am J Forensic Med Pathol 20:109-115, 1999

7. Coben $\mathrm{JH}$, Steiner CA: Hospitalization for firearm-related injuries in the United States, 1997. Am J Prev Med 24:I-8, 2003

8. Glapa M, Zorio M, Snyckers FD, Bowley DM, Yilmaz TH, Doll D, Degiannis E: Gunshot wounds to the head in civilian practice. Am Surg 75:233-226, 2009

9. lakhikhazhiev SK: Surgical services in a central regional hospital in for ballistic wounds during the armed conflicts. Voen Med Zh 330:35-39, 2009

10. Irfan FB, Hassan RU, Kumar R, Bhutta ZA, Bari E: Craniocerebral gunshot injuries in preschoolers. Childs Nerv Syst 26:61-66, 2010

11. Jandial R, Reichwage $B$, Levy $M$, Duenas V, Sturdivan L: Ballistics for the neurosurgeon. Neurosurgery 62:472-480, 2008

12. Krug EG, Powell KE, Dahlberg LL: Firearm-related deaths in the United States and 35 other high- and upper-middleincome countries. Int J Epidemiol 27:214-221, 1998

13. Molina DK, DiMaio VJ: Rifle wounds: A review of range and location as pertaining to manner of death. Am J Forensic Med Pathol 29: 201-205, 2008

14. Muhammad Khyani IA, Hafeez A, Farooq MU, Alam J: Endoscopic removal of bullet from orbital apex. J Coll Physicians Surg Pak 18:646-648, 2008

15. Murano T, Mohr AM, Lavery RF, Lynch C, Homnick AT, Livingston DH: Civilian craniocerebral gunshot wounds: An update in predicting outcomes. Am Surg 71:1009-1014, 2005

16. O'Neill PJ, Lumpkin MF, Clapp B, Kopelman TR, Matthews MR, Cox JC, Caruso DM, Feiz-Erfan I: Significant pediatric morbidity and mortality from intracranial ballistic injuries caused by nonpowder gunshot wounds: A case series. Pediatr Neurosurg 45:205-209, 2009

17. Ramasamy A, Harrison SE, Stewart MP, Midwinter M: Penetrating missile injuries during the Iraqi insurgency. Ann R Coll Surg Engl 91:551-558, 2009

18. Raymond D, Van Ee C, Crawford G, Bir C: Tolerance of the skull to blunt ballistic temporo-parietal impact. J Biomech 42:2479-2485, 2009

19. Reed AR, Welsh DG: Secondary injury in traumatic brain injury patients--a prospective study. S Afr Med J 92:221-224, 2002

20. Schyma P, Schyma C: Dangers of blank firearms--risk of injury and expert assessment. Versicherungsmedizin 52:141-146, 2000

21. Volgas DA, Stannard JP, Alonso JE: Ballistics: A primer for the surgeon. Injury 36:373-379, 2005

22. Yetiser S, Kahramanyol M: High-velocity gunshot wounds to the head and neck: A review of wound ballistics. Mil Med 163:346-351, 1998 